\section{US test of AIDS vaccines is broadened beyond VaxSyn}

\begin{abstract}
Washington. A controversial plan to conduct large-scale clinical trials of a single therapeutic AIDS vaccine has been modified to compare the efficacy of three vaccines and will be conducted by the National Institutes of Health (NIH) instead of the US Army.

The US Departments of Defense and of Health and Human Services, NIH's parent agency, agreed last week to spend \$23 million to test the efficacy of three potential vaccines on 9,000 people after the Army had made known its intention to proceed with a single trial of VaxSyn, a gp160 therapeutic vaccine produced by the Connecticut biotechnology company MicroGeneSys. Last autumn, the company successfully lobbied Congress to appropriate $\$ 20$ million for that purpose. NIH has agreed to provide the additional money for the expanded trials.
\end{abstract}

The new plan is a victory for scientists and AIDS activists, who argued strongly that it would be premature to conduct a large-scale trial of VaxSyn. A panel cochaired by NIH director Bernadine Healy and David Kessler, head of the Food and Drug Administration., last winter recommended the testing of several potential vaccines, but the Army was not required to heed their advice.

An announcement on the agreement, due late last week, was delayed as the Clinton administration tried to decide how to reconDOD want to do." conduct the trials. ment Action Group in New York. his case for the single vaccine trial. patients who are HIV-positive. cile language in last year's defence appropriations bill with its decision that the NIH should spend the money instead of the Army. "The White House is still trying to figure this one out", says a Senate staff member. "It is trying to steer a middle course between what the law says and what the NIH and the

The appropriations subcommittee is expected to discuss the change when the Senate returns next week from its two-week Easter recess. One possible solution is for the Army to award a contract to NIH to

AIDS activists are confident that multivaccine trials will soon begin. "It's what we wanted", says Gregg Gonsalves of the Treat-

But MicroGeneSys president Frank Volvovitz expresses scepticism that a multiple trial large enough to provide conclusive results can be done for $\$ 23$ million. Volvovitz was scheduled to meet Department of Defense officials earlier this week to press

The \$23-million trial is thought to involve giving each vaccine to 3,000 people, against the Army's original plan to test VaxSyn on 10,000 people. Either approach would represent the largest clinical trials so far of the ability of therapeutic vaccines to retard the onset of full-blown AIDS on

Colin Macilwain

\section{NIH genome centre begins build-up}

Washington. Twenty senior genome researchers are expected to join Francis Collins, the new director of the National Center for Human Genome Research at the US National Institutes of Health (NIH), in building an intramural programme that will focus on applying knowledge obtained in the human genome project.

Collins said last week that seven senior investigators - including two from his old base at the University of Michigan School of Medicine - have agreed to begin working at NIH in September and that he expects their number to increase to 20 , directing an overall staff of 200, by 1995 . NIH director Bernadine Healy says that such a wave of new talent would be "a critical example of the reversal of the brain drain from NIH". The new centre will broaden the existing \$100- million-a-year extramural gene-mapping effort at $\mathrm{NIH}$ (the Department of Energy will this year spend an additional $\$ 62$ million on the project) into DNA diagnostics, gene therapy and the search for disease genes.
President Bill Clinton has requested an increase of \$25 million in the fiscal year that begins on 1 October 1993 for the centre's intramural programme, an exceptional rate of growth when compared to the increase of 3.3 per cent requested for $\mathrm{NIH}$ as a whole. Even so, it is less than Collins had hoped for. He says that considerably more will be needed in fiscal year 1995 for "the critical mass we are hoping to achieve".

Achieving such growth will not be easy, however. Although Healy has been a strong proponent of setting up an intramural programme, she will be leaving on 30 June. If Congress does not grant NIH its wish, her successor will have to tax the other institutes to give Collins what he wants.

Collins, noted for his work in identifying genes for cystic fibrosis and, most recently, Huntington's disease, says he plans to continue spending at least half of his time at NIH doing science despite his administrative responsibilities as director of the genome centre.

\section{Clinton budget puts squeeze on accelerator labs}

Washington. US high-energy physicists face another year of tight operating budgets, low capital spending and falling utilization of existing facilities, according to the budget for fiscal year 1994 (beginning on 1 October 1993 ) proposed last week by President Bill Clinton.

Although the budget for the Department of Energy would increase research spending in the field by 5.5 per cent, to $\$ 627.8 \mathrm{mil}$ lion, the increase will be consumed by a doubling in major construction spending from \$43 million to \$86 million - meaning cuts in funding for operations and new equipment at five national laboratories.

Members of the department's High Energy Physics Advisory Panel (HEPAP) learned last week of reductions ranging from 11 per cent at the Stanford Linear Accelerator Center (SLAC) in California to 1 per cent in the $\$ 102$ million to be spent on university-based research. Four laboratories will each see reductions of around 2 per cent.

HEPAP will now ask the department to make revisions in health, safety and environmental regulations that cost the highenergy physics laboratories tens of millions of dollars a vear to implement. It will also ask for a firm completion date for the Superconducting Super Collider (SSC) in Texas, which under the president's budget request would be deferred from 1999 to around 2003

The physicists also want the Department of Energy and the National Science Foundation to complete quickly their review of whether to build the proposed 'B-meson factory' - an accelerator for which Clinton has requested \$36 million in 1994 in initial funding - at SLAC or at Cornell University in Ithaca, New York. The fear is that Congress will not appropriate the money this year unless a site has been chosen.

Restrictions on operating budgets have led to some expensive facilities being in experimental use for as little as eight weeks a year. Although several panel members complain that the discipline is now living off investments made in the 1980s, others question the wisdom of additional facilities such as the B-factory when the resources are lacking to operate existing ones.

The panel does not intend to review the work done last year by a panel chaired by Michael Witherell of the University of California at Santa Barbara, which set priorities for the field. But members are unhappy that nothing has happened so far on the Witherell recommendations and that political considerations have caused postponement of any decision on which facilities to curtail or close.

C. $\mathbf{M}$. 